



\title{
Upper Jurassic - Lower Cretaceous of the Danish Central Graben: structural framework and nomenclature
}

\author{
Peter Japsen, Peter Britze and Claus Andersen
}

\begin{abstract}
The Danish Central Graben is part of the mainly Late Jurassic complex of grabens in the central and southern North Sea which form the Central Graben. The tectonic elements of the Danish Central Graben in the Late Jurassic are outlined and compared to those in the Early Cretaceous based on reduced versions of published maps (1:200 000), compiled on the basis of all 1994 public domain seismic and well data. The Tail End Graben, a half-graben which stretches for about $90 \mathrm{~km}$ along the East North Sea High, is the dominant Late Jurassic structural feature. The Rosa Basin (new name) is a narrow, north-south-trending basin extending from the south-western part of the Tail End Graben. The Tail End Graben ceased to exist as a coherent structural element during the Early Cretaceous and developed into three separate depocentres: the Iris and Gulnare Basins to the north and the Roar Basin to the south (new names). The Early Cretaceous saw a shift from subsidence focused along the East North Sea High during the Late Jurassic to a more even distribution of minor basins within the Danish Central Graben.

The depth to the top of the Upper Jurassic - lowermost Cretaceous Farsund Formation reaches a maximum of $4800 \mathrm{~m}$ in the northern part of the study area, while the depth to the base of the Upper Jurassic reaches $7500 \mathrm{~m}$ in the Tail End Graben, where the Upper Jurassic attains a maximum thickness of $3600 \mathrm{~m}$. The Lower Cretaceous Cromer Knoll Group attains a maximum thickness of $1100 \mathrm{~m}$ in the Outer Rough Basin.
\end{abstract}

Keywords: North Sea, Danish Central Graben, Upper Jurassic, Lower Cretaceous, isochore maps, structure contour maps, structural nomenclature

Geological Survey of Denmark and Greenland, Geocenter Copenhagen, Øster Voldgade 10, DK-1350 Copenhagen K, Denmark. E-mail: pj@geus.dk

Mapping of the Danish Central Graben has provided a coherent homogeneous database for evaluating the main features of structural evolution during the Late Jurassic and the Early Cretaceous (Britze et al. 1995a, b, c, d). This mapping has highlighted the necessity for the definition of certain new structural elements and clarification of the established terminology. The aim of this article therefore is to present a brief description of the important tectonic elements of the area in the Late Jurassic - Early Cretaceous, illustrated by reduced versions of maps published at a scale of 1:200 000 (Britze et al. 1995a, b, c, d). In particular, we distinguish between the elements that were active during the Late Jurassic - earliest Cretaceous and those that came into existence during the deposition of the Cromer Knoll Group. This then provides the framework for subsequent detailed articles on the Upper Jurassic of the Danish Central Graben (Andsbjerg \& Dybkjær 2003, this volume; Johannessen 2003, this volume; Møller \& Rasmussen 2003, this volume). The introduction to the Upper Jurassic Lower Cretaceous structural geology of the Danish Central Graben is preceded by a brief account of the mapped horizons (Fig. 1) and the mapping procedures adopted. As discussed further below, the seismic boundary between rocks largely of Jurassic age and the overlying Lower Cretaceous Cromer Knoll Group is located 


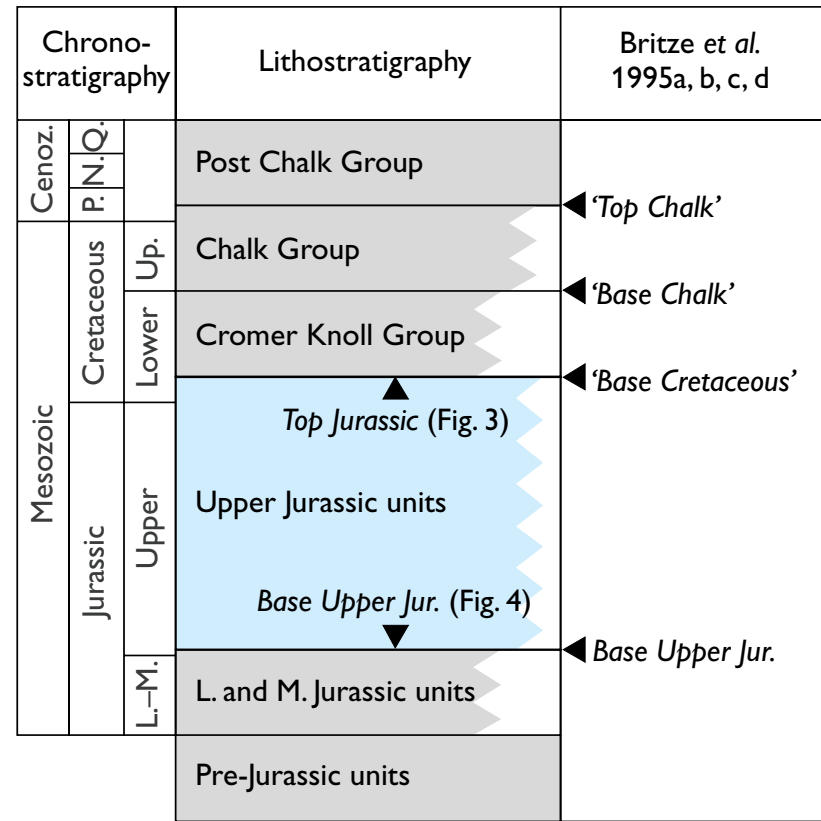

Fig. 1. Generalised stratigraphic scheme indicating the relative positions of the horizons mapped by Britze et al. (1995a, b, c, d) and the surfaces shown in Figures 3 and 4. Whereas the surfaces mapped by Britze et al. (1995a, b, c, d) are defined for every point in the study area, those of Figures 3 and 4 are only defined where the Upper Jurassic is defined in the Central Graben. Inverted commas (e.g. 'Top Chalk') are used to indicate that the referenced surface may not be present throughout (i.e. the Chalk may locally be absent). The main lithostratigraphic units applied in the mapping are the Post Chalk Group (Cenozoic excluding the Danian; Nielsen \& Japsen 1991), the Chalk Group (Upper Cretaceous Danian; Lieberkind et al. 1982), the Cromer Knoll Group (Deegan \& Scull 1977) and the term 'Upper Jurassic units' comprising the Lola, Heno, Farsund and Poul Formations. For details of the lithostratigraphic subdivision, see Michelsen et al. (2003, this volume). Jur, Jurassic; L, Lower; M, Middle; Up, Upper; Cenoz, Cenozoic; P, Palaeogene; N, Neogene; $\mathbf{Q}$, Quaternary.

at the top of the Farsund Formation which extends up into the lowermost Cretaceous (the boundary is of Late Ryazanian age). Thus, the term 'Upper/Late Jurassic' is used broadly in this paper so as to include the lowermost/earliest Cretaceous which genetically forms part of the Upper Jurassic succession.

\section{Regional setting}

The Danish Central Graben consists of a system of generally NNW-SSE-trending half-grabens bounded by the Coffee Soil Fault to the east towards the footwall block of the East North Sea Block, and by the Mid North Sea
High to the west (Figs 2-6). The rifting, which involved high rates of crustal stretching (Vejbæk 1992; Ineson et al. 2003, this volume), commenced during the Bajocian (Johannesen \& Andsbjerg 1993). The syn-rift sedimentary fill is mudstone-dominated and is very rich in organic matter at certain levels (Damtoft et al. 1992). The early development was characterised by fault-controlled subsidence and deposition in the eastern part, especially along north-south-trending segments of the Coffee Soil Fault (Korstgård et al. 1993). During the Kimmeridgian, the dominant tectonic trend shifted from the north-south fault direction inherited from the pre-Jurassic to a dominant NW-SE direction (Møller \& Rasmussen 2003, this volume); the depocentres shifted westwards and deposition gradually covered larger areas. Despite the overall extensional tectonic regime, compressional features have been reported, caused by oblique-slip movements between different graben segments or by re-adjustments at boundaries between opposite-dipping fault blocks (Sundsbø \& Megson 1993; Rasmussen 1995).

The extensional tectonic regime of the Late Jurassic continued in the Early Cretaceous, albeit with much reduced subsidence rates. Although subsidence patterns to some extent followed those of the Late Jurassic, there was a shift with new depocentres developing to the west (Figs 7, 8). The Lower Cretaceous deposits accumulated in local depocentres, partly as a result of reduced sediment supply, and partly due to accentuation of ridges and structural highs separating the subbasins. Block faulting gradually ceased after the Hauterivian, giving way to regional subsidence and mild inversion movements (Vejbæk 1986).

\section{Central Graben versus Central Trough}

The term 'Central Graben' has gained wide acceptance (Ziegler 1990), in preference to 'Central Trough', a term that was first proposed by Rønnevik et al. (1975). Their argument for adopting the term Central Trough for the "graben system of Permian-Cretaceous age" was that "The tectonic axis of the graben system does not coincide with the deepest part of the depocentre and this is the reason why the name trough is preferred over graben" (Rønnevik et al. 1975, p. 5). In contrast, Gowers \& Sæbøe (1985, p. 313) stated that "the Central Trough should be treated as a broad NW-trending zone of subsidence with some local highs only when discussing post midCretaceous geology". The Central Trough is consequently identified on a structural map of the base of the Cenozoic by Gowers \& Sæbøe (1985, fig. 1). When considering the 


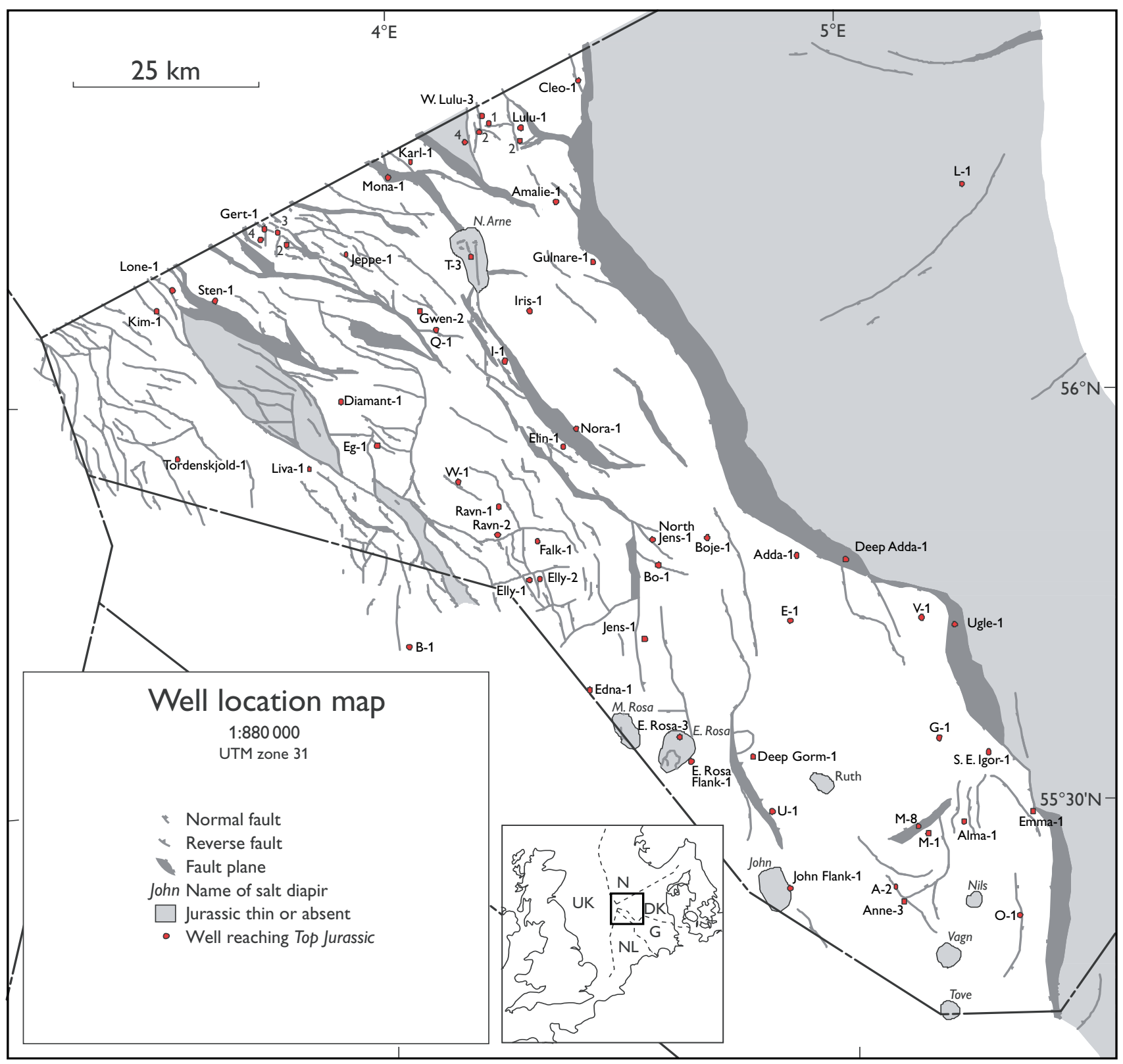

Fig. 2. Wells reaching Top Jurassic. Well database for the mapping incorporating all 1994 released wells plus the Alma-1 and Amalie-1 wells. National sectors of the North Sea: DK, Denmark; G, Germany; N, Norway; NL, the Netherlands; UK, United Kingdom.

pre mid-Cretaceous geology, the recommendation of Gowers \& Sæbøe (1985) was to refer to the individual structural elements within the area of the Central Trough.

We find the use of the term Central Trough confusing, and propose that the term Central Graben is used for the complex of grabens and half-grabens of mainly Late Jurassic age in the central and southern North Sea. Furthermore, we recommend that the term North Sea Basin (Ziegler 1990) is adopted when referring to the regional subsidence pattern of Late Cretaceous and Cenozoic post-rift sedimentation that was aligned over the former Mesozoic grabens.

\section{Subsurface mapping of the Danish Central Graben}

The structural depth and isochore maps presented here are reduced and simplified versions of a suite of fifteen maps published at a scale of 1:200 000 and covering up to $13000 \mathrm{~km}^{2}$ in the western part of the Danish North Sea sector (Britze et al. 1995a, b, c, d). The maps are part of the outcome of an integrated mapping project with the aim of modelling and mapping interval velocities and depths of the main post-Middle Jurassic units in the Danish Central Graben. The study is based on 


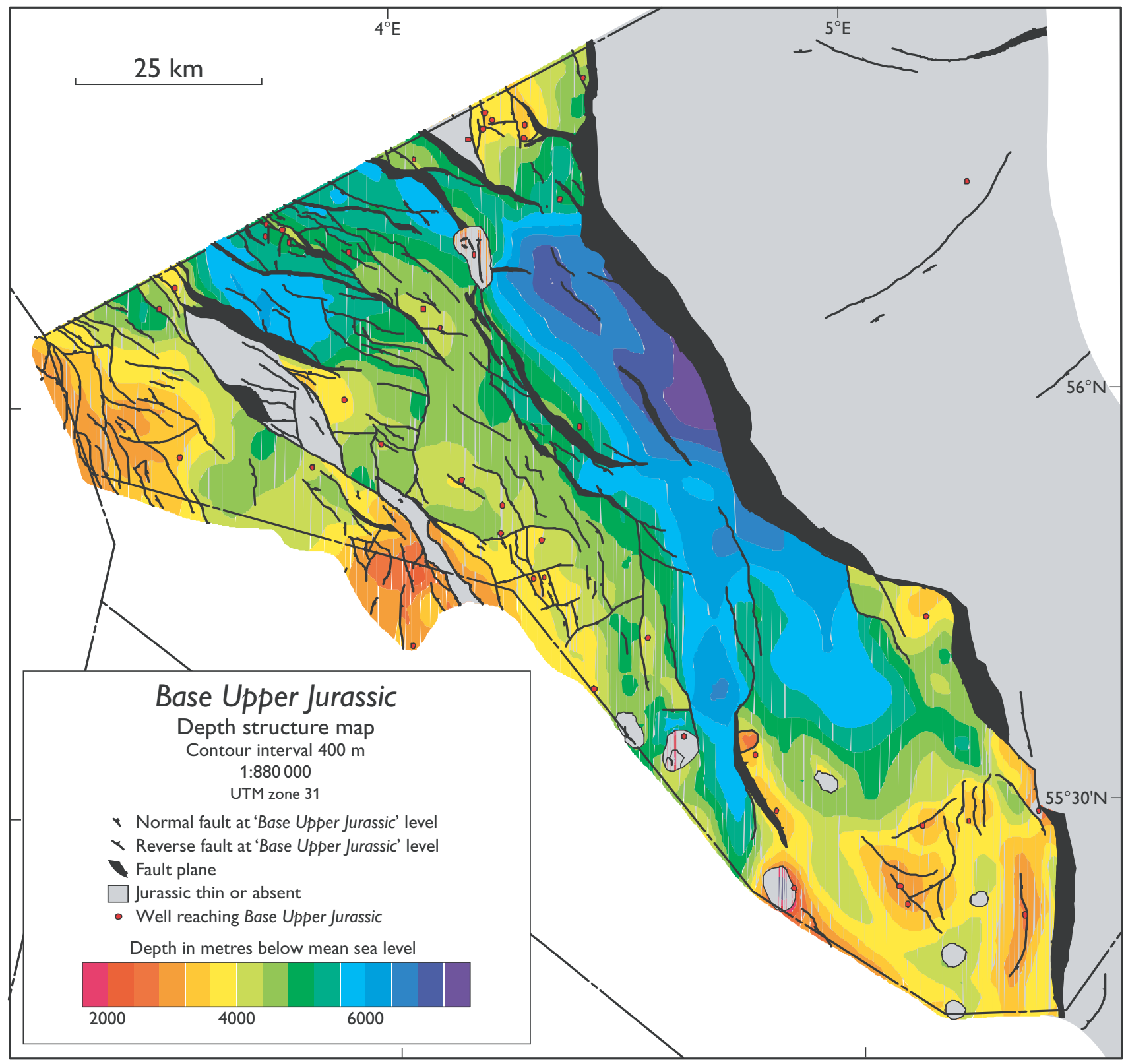

Fig. 3. Base Upper Jurassic structural depth map showing depth to the base of the Upper Jurassic units (Fig. 1). Modified after Britze et al. (1995d).

well data and time structure maps of well-defined marker horizons illustrating both the syn-rift and post-rift development of the area.

\section{Previous work}

The Central Graben was recognised as one of the main geological provinces in Denmark by Rasmussen (1978) based on seismic mapping by J.C. Baartman. The first structural outline of the Danish Central Graben was presented by Andersen et al. (1982), and the structural evolution of the Danish and Norwegian parts of the Central Graben was later discussed by Gowers \& Sæbøe (1985). Detailed analysis of the structural development and definition of the structural nomenclature for the Danish Central Graben was presented by Møller (1986) for the Middle and Upper Jurassic and by Vejbæk (1986) for the Lower Cretaceous. The structure of the Central 


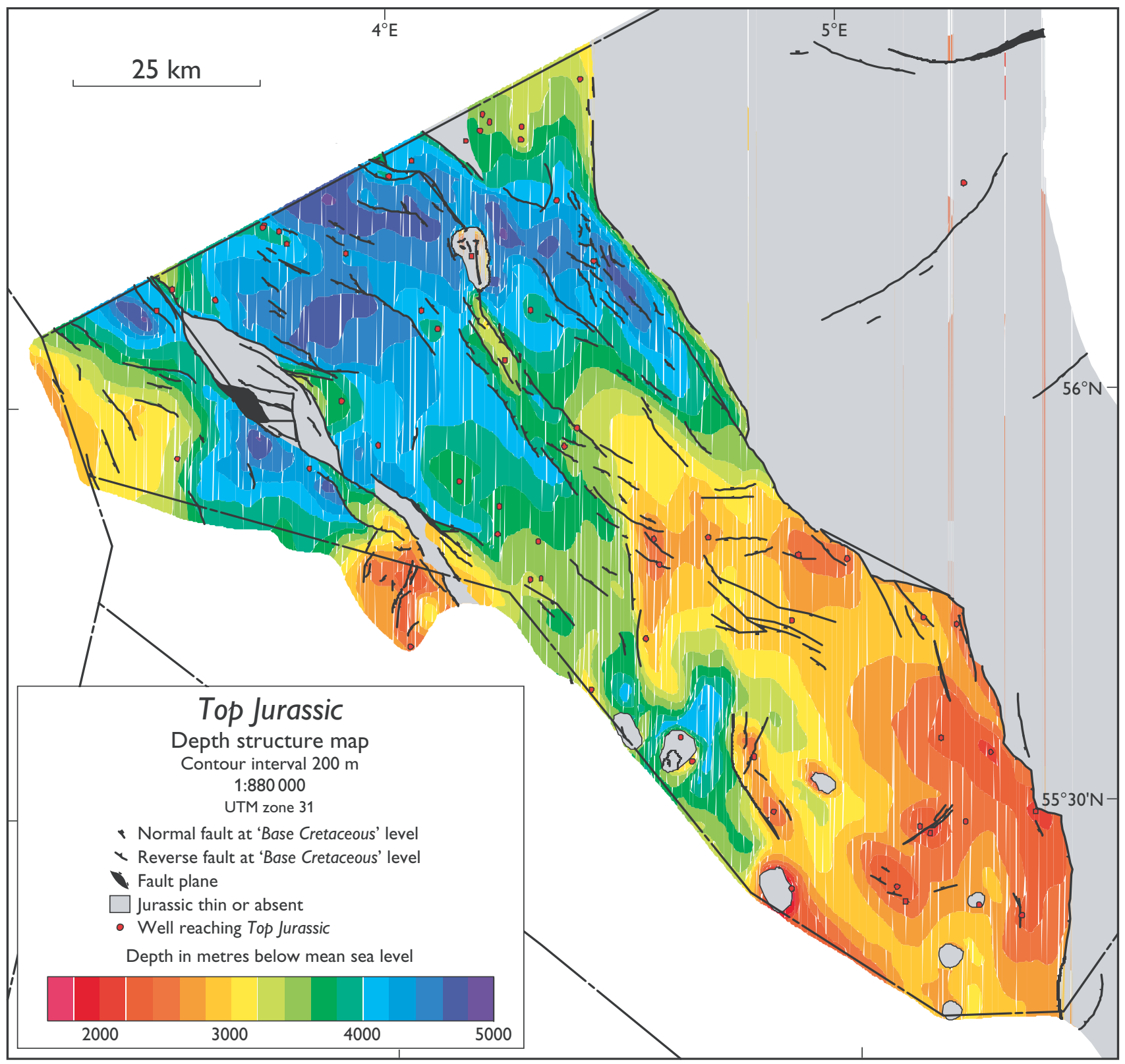

Fig. 4. Top Jurassic structural depth map showing depth to the top of the Upper Jurassic units (Fig. 1). Modified after Britze et al. (1995c).

Graben in the Norwegian and northernmost Danish sectors was further discussed by Gowers et al. (1993).

Four two-way time maps of the Jurassic in the Danish Central Graben were published by Møller (1986): Near base Middle Jurassic/Top pre-Jurassic, OxfordianKimmeridgian boundary, Late Kimmeridgian marker and Near top Jurassic/Base Cretaceous (1:500 000) (mapped surfaces are identified by italics in this paper). In addition, a map (1:800 000) was presented showing the thickness in metres of the Middle and Upper Jurassic.

\section{Database}

The mapped area covers the Danish Central Graben and part of the eastern footwall block, the East North Sea Block, which forms part of the Ringkøbing-Fyn High system of elevated basement blocks (Figs 5, 7). All 1994 public domain petroleum industry seismic and well data acquired on Danish territory form the basis for the study, with the addition of data from the Alma-1 and Amalie-1 wells. The well database comprises 96 released 


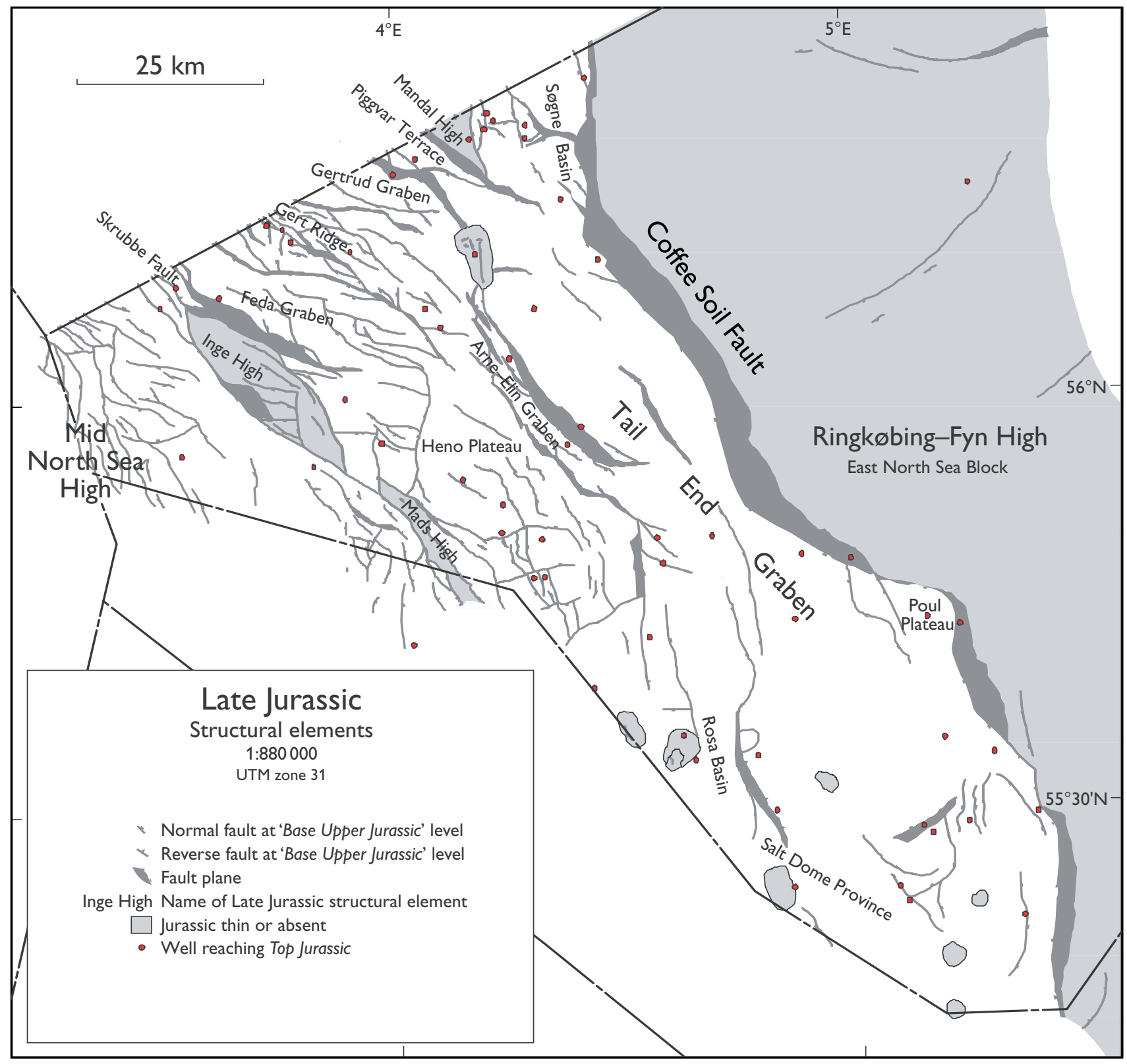

Fig. 5. Late Jurassic structural elements (Britze et al. 1995d). Based on the Upper Jurassic isochore (Fig. 6) and Møller (1986).

exploration and appraisal wells drilled, as a minimum, into the Chalk Group (Upper Cretaceous - Danian, Lieberkind et al. 1982). Of these wells, 62 drilled into Upper Jurassic units (Figs 1, 2). The lithostratigraphic subdivision of most of the wells is presented in Nielsen \& Japsen (1991). The seismic database varies in quality from 1979 2D sections to 1988 3D data (Rasmussen 1995; Kristensen et al. 1995), and comprises regional speculative surveys acquired during the early and mid1980s and proprietary surveys acquired by Mærsk Olie og Gas AS.

\section{Seismic markers}

In the eastern part of the Central Graben, the Upper Jurassic graben fill conformably overlies the Middle Jurassic. Here the Base Upper Jurassic seismic sequence boundary is picked in a trough above a strong peak that usually shows significant lateral continuity. This seismic boundary marks a general increase in acoustic impedance. The trough-peak relationship is believed to be enhanced by the interference of alternating sandstones, shales and coal beds in the uppermost part of 


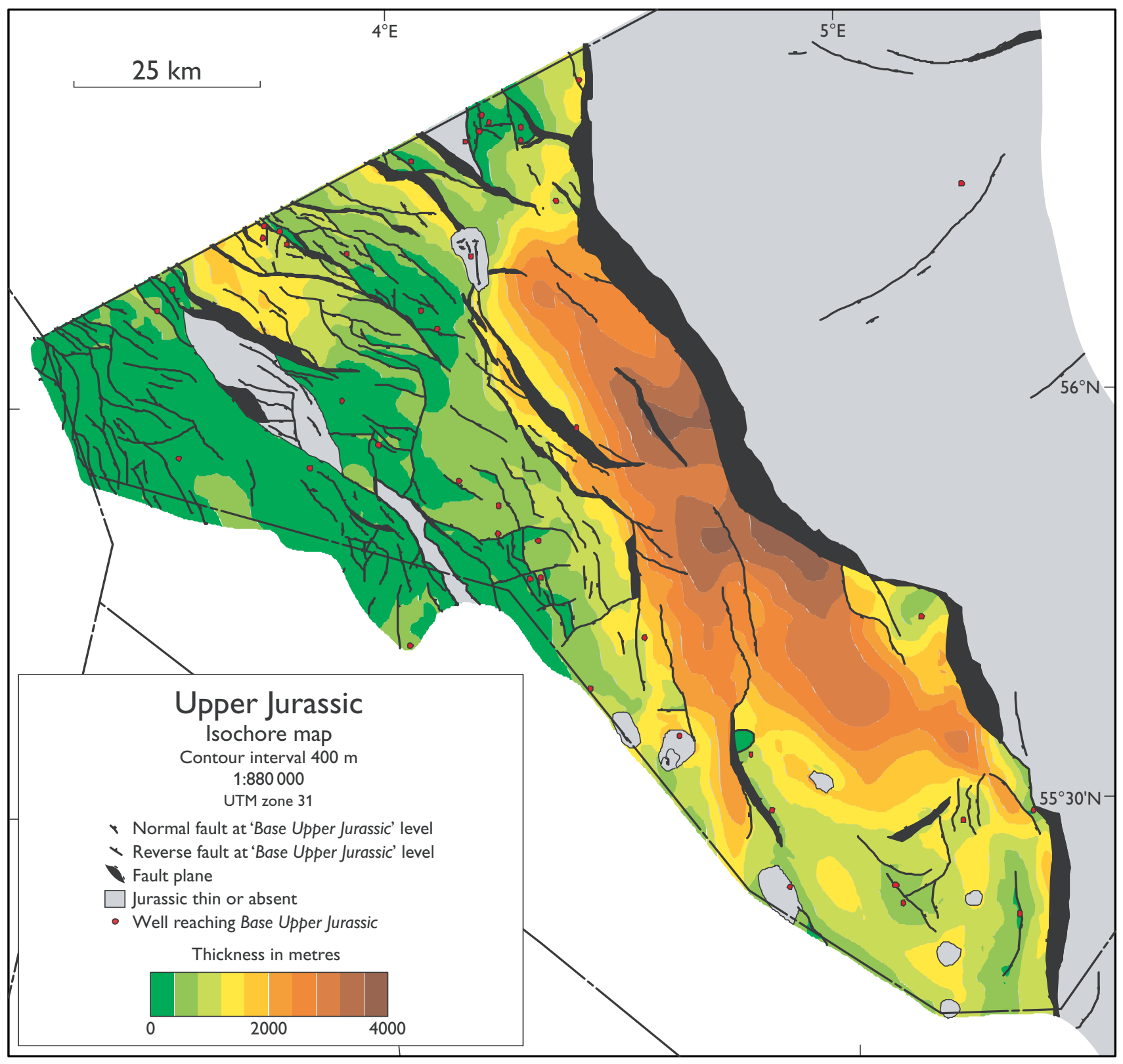

Fig 6. Upper Jurassic isochore showing the thickness of the Upper Jurassic units (Fig. 1). Modified after Britze et al. (1995d).

the Middle Jurassic. Further westwards, where the Upper Jurassic overlies a pre-Jurassic substratum, the seismic marker is recognised as a pronounced unconformity. Interpretation of the Base Upper Jurassic surface is complicated due to the great depth of burial (up to $6 \mathrm{sec}-$ onds two-way time), the structural complexity, and local interference of multiples caused by overlying, thick high-velocity chalk deposits, for example on the Heno Plateau where Lower Cretaceous strata are absent.

In basinal areas, the Top Jurassic marker is an easily identified seismic event marking the top of the low-veloc- ity Farsund Formation of Late Jurassic - earliest Cretaceous age (Jensen et al. 1986). Towards the basin margins, the overlying sequence onlaps Top Jurassic. Locally the Upper Jurassic sediments have been eroded and the Top Jurassic marker is recognised as an unconformity.

\section{Seismic mapping}

Four horizons were mapped throughout the study area to illustrate the structural evolution and to undertake 
layer-cake depth conversion (Fig. 1). The maps are thus not only defined by the presence of a given lithological unit (e.g. top Chalk Group), but rather by the base of all sediments above the unit (e.g. the base of the Cenozoic deposits, excluding the Danian). However, a simple nomenclature was chosen for the mapped horizons corresponding to the everyday usage ('Top Chalk') rather than applying a strict terminology, and inverted commas were adopted to indicate that the referenced surface may not be present throughout (i.e. the Chalk Group may locally be absent). Furthermore, a horizon name may represent a stratigraphic simplification; for example, the uppermost Farsund Formation, bounded by the 'TopJurassic' surface, may include rocks of earliest Cretaceous (Ryazanian) age.

The four horizons mapped are 'Top Chalk' - base of the Cenozoic deposits (excluding the Danian), 'Base Chalk' - base of the post-Early Cretaceous deposits, 'Base Cretaceous' - base of the post-Jurassic deposits and 'Base Upper Jurassic' - base of the post-Middle Jurassic deposits (Britze et al. 1995a, b, c, d). The 'Base Cretaceous' time map is an extension and revision of the Near top Jurassic/Base Cretaceous time map, published by Møller (1986). The Base Upper Jurassic time map is an extension and revision of the Near base MiddleJurassic/Top pre-Jurassic time map (Møller 1986). The map was merged with the Top Middle Jurassic structure map of the Søgne Basin - northern Tail End Graben by Korstgård et al. (1993). Both time maps were incorporated with unpublished regional interpretations and detailed mapping of hydrocarbon fields undertaken by the Geological Survey of Denmark and Greenland. The drafts of the time structure maps were compiled manually at a scale of 1:100 000. The final maps were produced digitally with the ZMAP Plus mapping system using a $200 \mathrm{~m}$ gridding interval.

The Base Upper Jurassic and TopJurassic depth maps shown in Figures 3 and 4 are the depth-converted images of two structural travel-time maps: 'Base Cretaceous' (Britze et al. 1995c) and 'Base Upper Jurassic' (Britze et al. 1995d). However, in order to focus on the Jurassic deposits, these maps are only defined where the Upper Jurassic is present in the Central Graben, whereas the original maps are defined throughout the area. The Upper Jurassic isochore map is thus equivalent to the thickness of the Upper Jurassic units comprising the Lola, Heno, Farsund and Poul Formations (Fig. 1).

\section{Depth conversion}

The depths to the surfaces are calculated by multi-layer depth conversion based on a study of different methods by Japsen (1994). The depth to TopJurassic is calculated by adding the thicknesses of the Chalk Group and the Cromer Knoll Group (Deegan \& Scull 1977) to the depth to the 'Top Chalk' surface (Britze et al. 1995a, b, c). The thickness of the Chalk overburden equivalent to the Post Chalk Group (Cenozoic excluding Danian, Nielsen \& Japsen 1991) is calculated by subdividing this layer into two at the mid-Miocene unconformity which represents the top of the overpressured zone (Japsen 1994). The thickness of each of these units are calculated by velocity-anomaly depth conversion whereby the thickness of each layer is calculated sequentially from the top downwards from the seismic travel-time thickness by assuming that the velocity of the layer increases linearly with depth (Japsen 1993). Laterally, however, velocity is calibrated to match well data. The velocity-anomaly map, the seismic traveltime maps, and the linear velocity parameters for each layer constitute input for velocity-anomaly depth conversion. The generated output are depth and intervalvelocity maps. The velocity-depth gradient applied for the upper and lower parts of the Post Chalk Group is 0.4 and $0.2 \mathrm{~m} / \mathrm{sec} / \mathrm{m}$, respectively, and for the Chalk Group and Cromer Knoll Group 0.7 and $0.5 \mathrm{~m} / \mathrm{sec} / \mathrm{m}$, respectively (Japsen 1994).

The depth to Base Upper Jurassic is calculated by adding the thickness of the Upper Jurassic to the depth to the Top Jurassic surface. The depth to Base Upper Jurassic is thus in total based on a five-layer depth conversion. No easily applied relationships between velocity and depth or travel time were found that could be used to predict the interval velocity of the Upper Jurassic (Japsen 1994). This is believed to be due to the complex geological and physical conditions as well as the restricted well database for this interval. The thickness of the Upper Jurassic is consequently calculated by multiplying the travel time of that unit by the interval velocity of the layer (Fig. 6).

\section{Results}

Upper Jurassic sediments are present throughout the main part of the Danish Central Graben except over the Inge, Mads and Mandal Highs and a number of salt diapirs (see discussion on the structural nomenclature below): East Rosa (the Dagmar Field), John, Middle 
Rosa (the Rolf Field), Nils (the Regnar Field), North Arne (the Svend Field), Ruth (the Skjold Field), Tove and Vagn (Fig. 2). Upper Jurassic sediments are thin or absent on the East North Sea Block. A thin succession of Late Jurassic age was encountered in the L-1 well, on the south-western flank of the Norwegian-Danish Basin (Figs 2, 7); the thickness of this succession is included in the Cromer Knoll Group isochore (Fig. 8).

The interval-velocity map of the Upper Jurassic represents contoured data from 54 wells of which 10 encountered more than $400 \mathrm{~m}$ of Upper Jurassic strata without penetrating the entire succession (Britze et al. 1995d). The latter wells are included to define the velocity field of the thick Upper Jurassic sequence in the Tail End Graben. The interval velocity of the Upper Jurassic is very low relative to depth in the Tail End Graben: 2.6 $\mathrm{km} / \mathrm{sec}$ in the Nora-1 well, which drilled through the Upper Jurassic interval in the depth range from 3500 to $4400 \mathrm{~m}$ below sea level (well locations are given on Fig. 2). Low velocities $(<2.6 \mathrm{~km} / \mathrm{sec})$ recorded in the northern part of the Tail End Graben are believed to be due to extreme overpressure caused by gas generation (Japsen 1994). A minimum value of $2.4 \mathrm{~km} / \mathrm{sec}$ was recorded in the North Jens-1 well. Velocities are relatively high in wells towards the west of the mapped area and adjacent to parts of the Coffee Soil Fault where deep-water sands originating from the East North Sea Block are found in the uppermost part of the Jurassic (Damtoft et al. 1992). The maximum interval velocity was recorded in the Ugle-1 well $(4.0 \mathrm{~km} / \mathrm{sec})$.

Depth to Base Upper Jurassic ranges from $2100 \mathrm{~m}$ in the John Flank-1 well to $7500 \mathrm{~m}$ in the deepest parts of the Tail End Graben, where the Upper Jurassic attains a maximum thickness of $3600 \mathrm{~m}$ of which a maximum of $1400 \mathrm{~m}$ has been drilled (the G-1 well) (Figs 3, 6). Depth to Top Jurassic ranges from $1700 \mathrm{~m}$ in the John Flank-1 well to $4800 \mathrm{~m}$ at the base of several Early Cretaceous depocentres in the northern parts of the Central Graben (Fig. 4). The maximum thicknesses of the Cromer Knoll Group are found in the Outer Rough Basin (1100 m; Figs 7, 8). Thicknesses of more than 800 $\mathrm{m}$ are estimated in the $\AA \mathrm{l}$, Iris and Roar Basins and in the Feda, Gertrud and Arne-Elin Grabens.

\section{Late Jurassic structural elements}

In the following, a brief presentation of the Late Jurassic structural elements is given with special emphasis on differences relative to the description by Møller (1986). The spatial relationship between these elements (Fig. 5)
Table 1. Structural nomenclature for the Danish Central Graben

\begin{tabular}{llcc}
\hline Structural element & \multicolumn{1}{c}{ Reference } & \multicolumn{2}{c}{ Age } \\
& & L. Jur. & E. Cret. \\
\hline Ål Basin & Gowers et al. (1993) & - & x \\
Arne-Elin Graben & Møller (1986),Vejbæk (1986) & x & x \\
Central Graben & Rasmussen (1978) & x & x \\
East North Sea Block & Rasmussen (1978) & x & x \\
Feda Graben & Gowers \& Sæbøe (1985) & x & x \\
Gert Ridge & Møller (1986),Vejbæk (1986) & x & x \\
Gertrud Graben & Møller (1986),Vejbæk (1986) & x & x \\
Gulnare Basin & new name & - & x \\
Heno Plateau & Møller (1986),Vejbæk (1986) & x & x \\
Inge High & Møller (1986),Vejbæk (1986) & x & x \\
Iris Basin & new name & - & x \\
Mads High & Møller (1986),Vejbæk (1986) & x & x \\
Mandal High & Rønnevik et al. (1975) & x & x \\
Mid North Sea High & Rasmussen (1978) & x & x \\
Outer Rough Basin & Gowers \& Sæbøe (1985) & - & x \\
Piggvar Terrace & Gowers et al. (1993) & x & - \\
Pollerne Ridge & Vejbæk (1986) & - & x \\
Poul Plateau & Møller (1986) & x & x \\
Ringkøbing-Fyn High & Rasmussen (1978) & x & x \\
Roar Basin & new name & - & x \\
Rosa Basin & new name & x & - \\
Salt Dome Province & Møller (1986),Vejbæk (1986) & x & x \\
Skrubbe Fault & Gowers \& Sæbøe (1985) & x & x \\
Søgne Basin & Gowers \& Sæbøe (1985) & x & - \\
Tail End Graben & Andersen et al. (1982) & x & - \\
\hline ECret. Eary Cre & & &
\end{tabular}

E. Cret. : Early Cretaceous

L. Jur. : Late Jurassic

are depicted on the Upper Jurassic isochore map (Fig. 6). The terminology follows that of Møller (1986) where reference to other studies is not indicated (Table 1).

The Tail End Graben (Andersen et al. 1982) is the dominant Late Jurassic structural element in the Danish Central Graben. It is a half-graben bounded to the east by the generally NW-SE-trending segments of the Coffee Soil Fault. The Tail End Graben accumulated up to $3600 \mathrm{~m}$ of sediments during the Late Jurassic, and it stretches over a length of about $90 \mathrm{~km}$. Thicknesses in excess of $2000 \mathrm{~m}$ are estimated to be present within an area from the Gulnare-1 well in the north to the G-1 well in the south. The depocentre of the Tail End Graben shifted westwards during the Late Jurassic while faulting shifted from north-south to NNW-SSE trends (Møller \& Rasmussen 2003, this volume). Towards the north, the Tail End Graben grades into the Piggvar Terrace (Gowers et al. 1993), and the north-south oriented Danish part of the Søgne Basin (Gowers \& Sæbøe 1985). In the south, the Tail End Graben extends into the nar- 


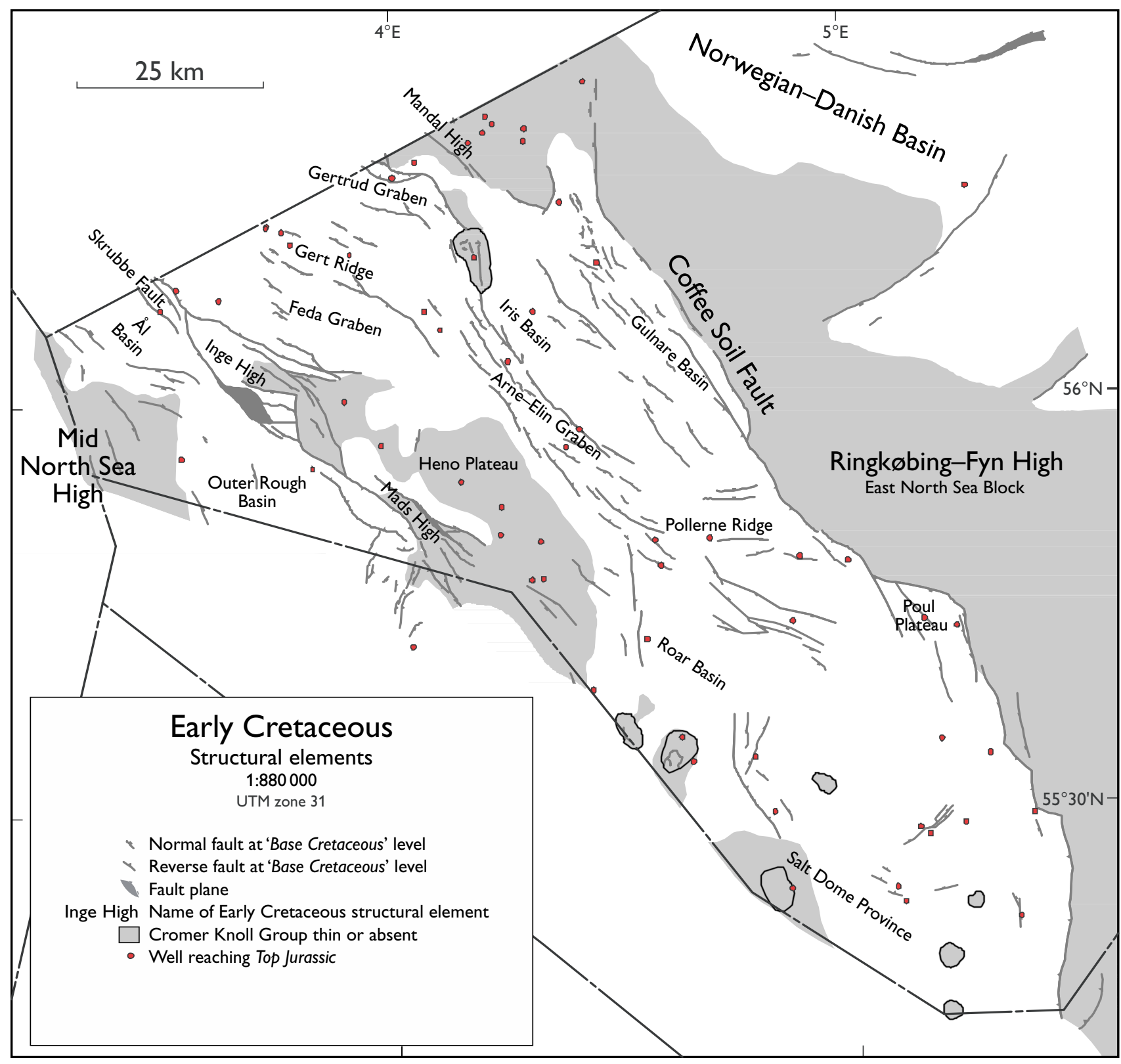

Fig. 7. Early Cretaceous structural elements (Britze et al. 1995c). Based on the Cromer Knoll Group isochore (Fig. 7) and Vejbæk (1986).

row north-south oriented Rosa Basin (new name) and grades into the Salt Dome Province, a region dominated by halokinetic features. The Poul Plateau with a reduced thickness of Upper Jurassic, is adjacent to a shift in the orientation of the Coffee Soil Fault.

The Piggvar Terrace (Gowers et al. 1993) is a narrow, NW-SE-trending segment separated by major normal faults from the Mandal High (Rønnevik et al. 1975) to the east and the Gertrud Graben to the west; it extends further north into Norwegian waters. Upper
Jurassic thicknesses reach $800 \mathrm{~m}$ on the Piggvar Terrace adjacent to the Mandal High.

The Søgne Basin (Gowers \& Sxbøe 1985) is a halfgraben that has a depocentre along the Coffee Soil Fault in the north-eastern part of the Danish Central Graben and continues into Norwegian waters. Its evolution is similar to the Salt Dome Province with relatively thick Triassic - lower Upper Jurassic sequences (Møller 1986). A hiatus spanning the latest Jurassic increases in magnitude towards the Mandal High where the Jurassic is 


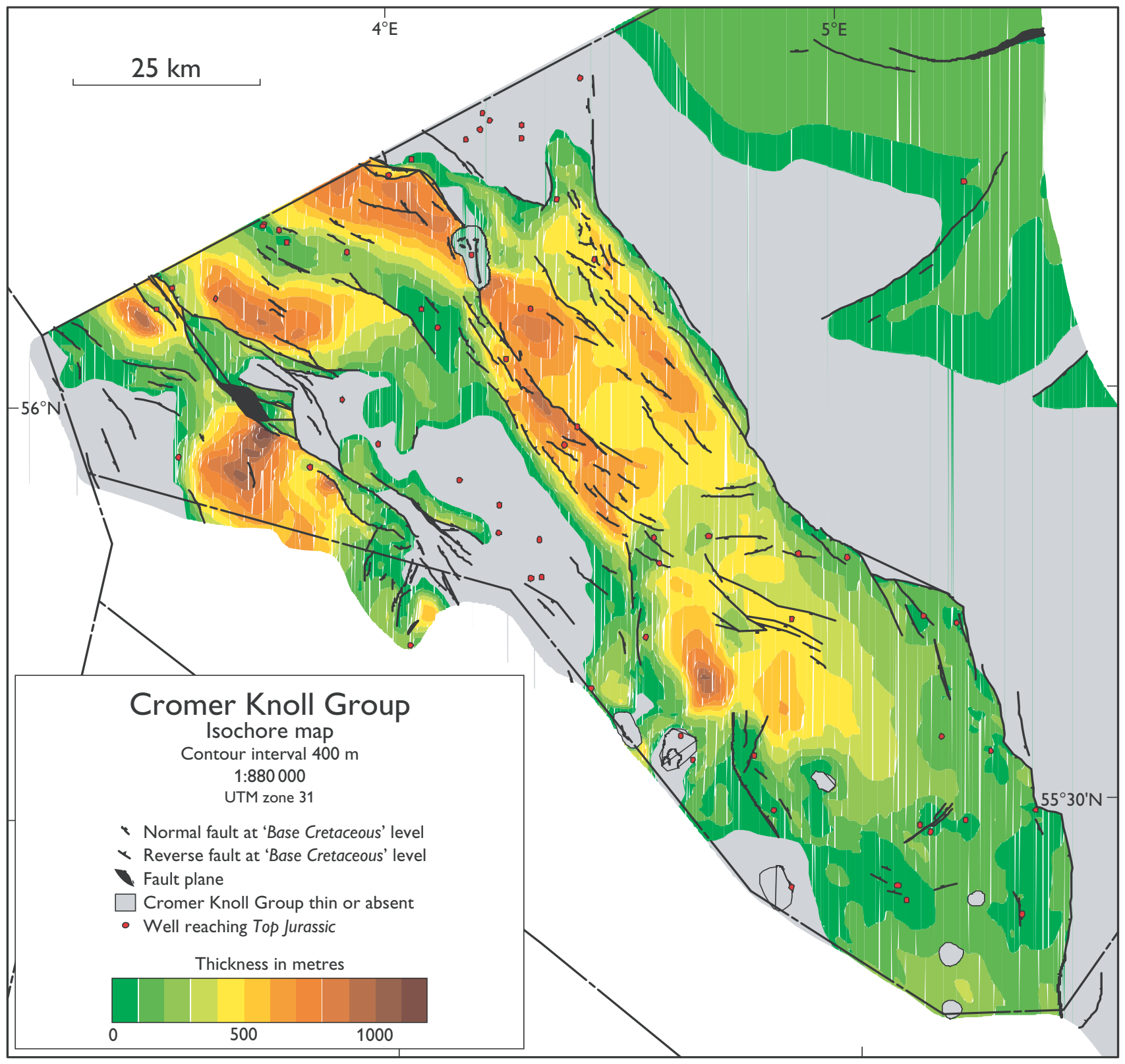

Fig. 8. Cromer Knoll Group isochore. Note that although the Cromer Knoll Group is not recognised outside the Central Graben, the map also depicts the thickness of Lower Cretaceous strata (including a thin Upper Jurassic section) in the south-western part of the Norwegian-Danish Basin. Modified from Britze et al. (1995c).

absent (Andsbjerg \& Dybkjær 2003, this volume). However, the preserved pre-Kimmeridgian Jurassic sequences in the Søgne Basin show no evidence of any syndepositional movements, an observation that suggests post-Kimmeridgian rotation of the Mandal High - Søgne Basin area.

The Rosa Basin (new name) is a narrow, north-southtrending basin that extends from the south-western part of the Tail End Graben into the Salt Dome Province. The Rosa Basin is limited by normal faults to the east and to the west, and the thickness of the Upper Jurassic exceeds $2000 \mathrm{~m}$ along the eastern bounding fault. The basin is named after the East Rosa salt diapir to the west.

The Feda Graben that continues north into Norwegian waters is the most prominent feature in the north-western part of the mapped area; it dips towards the west, where up to $1600 \mathrm{~m}$ of Upper Jurassic sediments accumulated along the Skrubbe Fault (Gowers et al. 1993) towards the Mid North Sea and Inge Highs. It is separated from the Gertrud Graben which dips to the east 
by the narrow Gert Ridge that is interpreted to have come into existence as a high during the earliest Cretaceous while the uppermost Farsund Formation was being deposited (Møller \& Rasmussen 2003, this volume). Towards the south, these depocentres grade into the Heno Plateau, characterised by intermediate thicknesses of Upper Jurassic sediments, and dominated by a mosaic of minor fault blocks.

The Arne-Elin Graben separates the Heno Plateau from the Tail End Graben. It is a pull-apart basin, related to left-lateral oblique-slip movements according to Vejbæk (1986) and Korstgård et al. (1993); the bounding faults were inverted during the Cretaceous (Møller 1986).

The Mid North Sea High (Rasmussen 1978) is covered by a thin veneer of Upper Jurassic sediments, and constitutes the western part of the Danish Central Graben. It is bounded to the east by the Inge and Mads Highs where the Jurassic is absent, and is characterised by a large number of minor, basement-attached faults.

\section{Early Cretaceous structural elements}

In the following, a brief presentation of the Early Cretaceous structural elements is given with special emphasis on differences relative to the description by Vejbæk (1986). The spatial relationships between these elements (Fig. 7) are depicted on the Cromer Knoll Group isochore map (Fig. 8). The maps of the Early Cretaceous geology are included here to emphasise the differences between the structural elements that were active during the Late Jurassic - earliest Cretaceous and those that came into existence during the deposition of the Cromer Knoll Group. The terminology follows that of Vejbæk (1986) where reference to other studies is not indicated (Table 1).

The Al Basin (Gowers et al. 1993) and the Outer Rough Basin (Gowers \& Sæbøe 1985) are located in the western part of the mapped area and separate the Mid North Sea High from the Inge High and the Mads High. These two basins mainly developed during the Cretaceous, as pointed out by Møller (1986), and are thus only included on the map of Early Cretaceous structural elements. The Ål Basin was referred to as the Grensen Nose by Møller (1986) and Vejbæk (1986), but this term was originally applied to a structural spur protruding from the Mid North Sea High (Gowers et al. 1993), and is mainly located in Norwegian waters.

The Heno Plateau, where Lower Cretaceous sediments are thin or absent, grades northwards into the NW-SE-trending depocentres of the Feda Graben and the Gertrud Graben separated by the narrow Gert Ridge. The Heno Plateau is bounded to the east by the Arne-Elin Graben. The term Lindesnes Ridge was applied by Gowers \& Sæbøe (1985) to a Late Cretaceous - Palaeogene inversion structure in the Feda Graben. The Skrubbe Fault (Gowers \& Sæbøe 1985) is a complex fault zone separating the Ål Basin from the Feda Graben, north of the Inge High.

The Iris Basin and Gulnare Basin (new names) are two separate depocentres that developed in Early Cretaceous times in the northern parts of the Late Jurassic Tail End Graben. Salt withdrawal is believed to have played a role in the formation of these depocentres (Korstgård et al. 1993); the Iris Basin is only separated from the Gertrud Graben by the North Arne salt diapir. To the north, the Mandal High was an elevated feature and probably experienced erosion during Early Cretaceous times (see above). The east-west-trending Pollerne Ridge separates these basins from the Roar Basin (new name) farther to the south. All three new basin names are taken from local wells. The Cromer Knoll Group is thinly developed in the Salt Dome Province to the south.

\section{Conclusions}

The Danish Central Graben is part of the mainly Late Jurassic complex of grabens which form the North Sea Central Graben. The Tail End Graben is the dominant Late Jurassic structural feature in the Danish Central Graben. Up to $3600 \mathrm{~m}$ of Upper Jurassic - lowermost Cretaceous sediments accumulated in the Tail End Graben, where deposits in excess of 2000 m thick are encountered for about $90 \mathrm{~km}$ along the NW-SE-trending Coffee Soil Fault. The Rosa Basin (new name) is a narrow, north-south-trending basin extending from the south-western part of the Tail End Graben. The Tail End Graben ceased to exist as a coherent structural element during the Early Cretaceous and developed into three separate depocentres: the Iris, Gulnare and Roar Basins (new names). The Early Cretaceous saw a shift from subsidence focused along the Coffee Soil Fault during the Late Jurassic to a more even distribution of minor basins within the Danish Central Graben. To the west, the Al Basin (formerly termed the Grensen Nose by Møller 1986) and the Outer Rough Basin mainly developed during the Early Cretaceous. The thickness of the Cromer Knoll Group ranges from 700 to $1100 \mathrm{~m}$ in the depocentres. 


\section{Acknowledgements}

The maps are part of the results of an integrated mapping project sponsored by the Amoco 3rd Round Group, comprising Amoco Denmark, FLS-Energy, DENERCO, and DOPAS. Regional mapping of the Danish Central Graben has been undertaken at the Survey in the course of the last 20 years. Hence many of our former and present colleagues have contributed significantly to the maps presented here: Ioannis Abatzis, Morten Sparre Andersen, Torben Bidstrup, Carsten Langtofte, Kurt Milthers, Carlos Møller, Jens Jørgen Møller, Kurt Damtoft Poulsen, Erik Skovbjerg Rasmussen and Ole Valdemar Vejbæk. Comments from the referees, G.M. Sykes and J.A. Korstgård, and the editors significantly improved the manuscript.

\section{References}

Andersen, C., Olsen, J.C., Michelsen, O. \& Nygaard, E. 1982: Structural outline and development. In: Michelsen, O. (ed.): Geology of the Danish Central Graben. Danmarks Geologiske Undersøgelse Serie B 8, 9-26.

Andsbjerg, J. \& Dybkjær, K. 2003: Sequence stratigraphy of the Jurassic of the Danish Central Graben. In: Ineson, J.R. \& Surlyk, F. (eds): The Jurassic of Denmark and Greenland. Geological Survey of Denmark and Greenland Bulletin 1, 265-300 (this volume).

Britze, P., Japsen, P. \& Andersen, C. 1995a: Geological map of Denmark, 1:200 000. The Danish Central Graben. 'Top Chalk' and the Post Chalk Group (two-way traveltime, depth and interval velocity). Danmarks Geologiske Undersøgelse Kortserie 47, 7 pp., 3 maps.

Britze, P., Japsen, P. \& Andersen, C. 1995b: Geological map of Denmark, 1:200 000. The Danish Central Graben. 'Base Chalk' and the Chalk Group (two-way traveltime and depth, interval velocity and isochore). Danmarks Geologiske Undersøgelse Kortserie 48, 7 pp., 4 maps.

Britze, P., Japsen, P. \& Andersen, C. 1995c: Geological map of Denmark, 1:200 000. The Danish Central Graben. 'Base Cretaceous' and the Cromer Knoll Group (two-way traveltime and depth, interval velocity and isochore). Danmarks Geologiske Undersøgelse Kortserie 49, 7 pp., 4 maps.

Britze, P., Japsen, P. \& Andersen, C. 1995d: Geological map of Denmark, 1:200 000. The Danish Central Graben. 'Base Upper Jurassic' and the Upper Jurassic (two-way traveltime and depth, interval velocity and isochore). Danmarks Geologiske Undersøgelse Kortserie 50, 7 pp., 4 maps.

Damtoft, K., Nielsen, L.H., Johannessen, P.N., Thomsen, E. \& Andersen, P.R. 1992: Hydrocarbon plays of the Danish Central Trough. In: Spencer, A.M. (ed.): Generation, accumulation and production of Europe's hydrocarbons II. European Association of Petroleum Geoscientists Special Publication 2, $35-58$.
Deegan, C.E. \& Scull, B.J. 1977: A standard lithostratigraphic nomenclature for the central and northern North Sea. Institute of Geological Sciences Report 77/25, 36 pp. London: Her Majesty's Stationery Office.

Gowers, M.B. \& Sæbøe, A. 1985: On the structural evolution of the Central Trough in the Norwegian and Danish sectors of the North Sea. Marine and Petroleum Geology 2, 298-318.

Gowers, M.B., Holtar, E. \& Swensson, E. 1993: The structure of the Norwegian Central Trough (Central Graben area). In: Parker, J.R. (ed.): Petroleum geology of Northwest Europe: proceedings of the 4th conference, 1245-1254. London: Geological Society.

Ineson, J.R., Bojesen-Koefoed, J.A., Dybkjær, K. \& Nielsen, L.H. 2003: Volgian-Ryazanian 'hot shales' of the Bo Member (Farsund Formation) in the Danish Central Graben, North Sea: stratigraphy, facies and geochemistry. In: Ineson, J.R. \& Surlyk, F. (eds): The Jurassic of Denmark and Greenland. Geological Survey of Denmark and Greenland Bulletin 1, 403-436 (this volume).

Japsen, P. 1993: Influence of lithology and Neogene uplift on seismic velocities in Denmark: Implications for depth conversion of maps. American Association of Petroleum Geologists Bulletin 77, 194-211.

Japsen, P. 1994: Retarded compaction due to overpressure deduced from a seismic velocity/depth conversion study in the Danish Central Trough, North Sea. Marine and Petroleum Geology 11, 715-733.

Jensen, T.F., Holm, L., Frandsen, N. \& Michelsen, O. 1986: Jurassic - Lower Cretaceous lithostratigraphic nomenclature for the Danish Central Trough. Danmarks Geologiske Undersøgelse Serie A 12, 65 pp.

Johannessen, P.N. 2003: Sedimentology and sequence stratigraphy of paralic and shallow marine Upper Jurassic sandstones in the northern Danish Central Graben. In: Ineson, J.R. \& Surlyk, F. (eds): The Jurassic of Denmark and Greenland. Geological Survey of Denmark and Greenland Bulletin 1, 367-402 (this volume)

Johannessen, P.N. \& Andsbjerg, J. 1993: Middle to Late Jurassic basin evolution and sandstone reservoir distribution in the Danish Central Trough. In: Parker, J.R. (ed.): Petroleum geology of Northwest Europe: proceedings of the 4th conference, 271-283. London: Geological Society.

Korstgård, J.A., Lerche, I., Mogensen, T.E. \& Thomsen, R.O. 1993 Salt and fault interactions in the north-eastern Danish Central Graben: observations and inferences. Bulletin of the Geological Society of Denmark 40, 197-255.

Kristensen, L., Dons, T., Maver, K.G. \& Schiøler, P. 1995: A multidisciplinary approach to reservoir subdivision of the Maastrichtian chalk in the Dan Field, Danish North Sea. American Association of Petroleum Geologists Bulletin 79 , 1650-1660.

Lieberkind, K., Bang, I., Mikkelsen, N. \& Nygaard, E. 1982: Late Cretaceous and Danian limestone. In: Michelsen, O. (ed.): Geology of the Danish Central Graben. Danmarks Geologiske Undersøgelse Serie B 8, 49-62.

Michelsen, O., Nielsen, L.H., Johannessen, P.N., Andsbjerg, J. \& Surlyk, F. 2003: Jurassic lithostratigraphy and stratigraphic 
development onshore and offshore Denmark. In: Ineson, J.R. \& Surlyk, F. (eds): The Jurassic of Denmark and Greenland. Geological Survey of Denmark and Greenland Bulletin 1, 147-216 (this volume).

Møller, J.J. 1986: Seismic structural mapping of the Middle and Upper Jurassic in the Danish Central Trough. Danmarks Geologiske Undersøgelse Serie A 13, 37 pp.

Møller, J.J. \& Rasmussen, E.S. 2003: Middle Jurassic - Early Cretaceous rifting of the Danish Central Graben. In: Ineson, J.R. \& Surlyk, F. (eds): The Jurassic of Denmark and Greenland. Geological Survey of Denmark and Greenland Bulletin 1, 247-264 (this volume).

Nielsen, L.H. \& Japsen, P. 1991: Deep wells in Denmark 1935-1990. Lithostratigraphic subdivision. Danmarks Geologiske Undersøgelse Serie A 31, 179 pp.

Rasmussen, E.S. 1995: Structural evolution of the Gert-Mjølner area. Marine and Petroleum Geology 12, 377-385.

Rasmussen, L.B. 1978: Geological aspects of the Danish North Sea sector. Danmarks Geologiske Undersøgelse III. Række 44, 85 pp.
Rønnevik, H.C., van den Bosch, W. \& Bandlien, E.H. 1975: A proposed nomenclature for the main structural features in the Norwegian North Sea. In: Finstad, K.G. \& Selley, R.C. (coordinators): Jurassic Northern North Sea Symposium, Stavanger, 28-30 September, 1975. Norwegian Petroleum Society (NPF) Proceedings. JNNS/18, $1-16$.

Sundsbø, G.O. \& Megson, J.B. 1993: Structural styles in the Danish Central Graben. In: Parker, J.R. (ed.): Petroleum geology of Northwest Europe: proceedings of the 4th conference, 12551267. London: Geological Society.

Vejbæk, O.V. 1986: Seismic stratigraphy and tectonic evolution of the Lower Cretaceous of the Danish Central Trough. Danmarks Geologiske Undersøgelse Serie A 11, 46 pp.

Vejbæk, O.V. 1992: Geodynamic modelling of the Danish Central Trough. In: Larsen, R.M. et al. (eds): Structural and tectonic modelling and its application to petroleum geology. Norwegian Petroleum Society (NPF) Special Publication 1, 1-17.

Ziegler, P.A. 1990: Geological atlas of western and central Europe, 2nd edition, 239 pp. Amsterdam: Elsevier for Shell Internationale Petroleum Maatschappij.

Manuscript received 2 February 1996; revision accepted 22 December 1997. 